\title{
Mineralization and Crop Uptake of Nitrogen from Textile Manufacturing Wastewater Sludge Cake
}

\author{
T. P. McGonigle, ${ }^{1}$ E. G. Beauchamp, ${ }^{2}$ L. J. Evans, ${ }^{2}$ and C. J. Wells ${ }^{3}$ \\ ${ }^{1}$ Department of Biology, Brandon University, Brandon, MB, Canada R7A 6A9 \\ ${ }^{2}$ School of Environmental Sciences, University of Guelph, Guelph, ON, Canada N1G 2W1 \\ ${ }^{3}$ Du Pont Canada Inc., P.O. Box 611, Maitland, ON, Canada KOE 1 P0
}

Correspondence should be addressed to T. P. McGonigle, mcgoniglet@brandonu.ca

Received 19 May 2011; Revised 11 July 2011; Accepted 11 July 2011

Academic Editor: Giuseppe Corti

Copyright (c) 2012 T. P. McGonigle et al. This is an open access article distributed under the Creative Commons Attribution License, which permits unrestricted use, distribution, and reproduction in any medium, provided the original work is properly cited.

Wastewater sewage sludge cake from textile manufacturing was evaluated by soil incubation experiments and a greenhouse experiment for use as a soil amendment to provide crop N. Although the sludge had $96 \%$ of N in organic combination, $20 \%$ of total sludge $\mathrm{N}$ was released to soil as mineral $\mathrm{N}$ over 28 days. $\mathrm{N}$ mineralization from the sludge was indistinguishable from that seen for alfalfa shoot in parallel incubations. However, nitrification inhibition was seen for the alfalfa amendment. Soil respiration was low for the sludge treatments compared to the alfalfa treatments, suggesting that carbon substrates in the sludge were less easily broken down. A second incubation experiment indicated that fine fragmentation of the sludge is not necessary to ensure mineralization proceeds. In a greenhouse experiment, sludge $\mathrm{N}$ was approximately $25 \%$ as available to Zea mays $\mathrm{L}$. as $\mathrm{NH}_{4} \mathrm{NO}_{3}$. The textile manufacturing sludge offered potential to offset $\mathrm{N}$ fertilizer requirement.

\section{Introduction}

Sewage sludges are generated by the treatment of wastewater streams in municipal and industrial installations [1]. The composition of these materials varies considerably. Sewage sludge from water treatment plants in Ontario, Canada, were reported [2] to have $4 \%-8 \%$ solids by mass $(n=4)$, whereas mechanically dewatered sludge normally contains up to $30 \%$ solids by mass [3]. A comparison of aerobic sewage sludges [4] gave ranges of values for total $\mathrm{N}$ from $5-76 \mathrm{~g} \mathrm{~kg}^{-1}(n=$ 38) and $\mathrm{NH}_{4}-\mathrm{N}$ from $0.03-11.3 \mathrm{~g} \mathrm{~kg}^{-1}(n=33)$. Corresponding ranges given by [5] are organic $\mathrm{N}$ from 13$65 \mathrm{~g} \mathrm{~kg}^{-1}$ and $\mathrm{NH}_{4}-\mathrm{N}$ from $0.4-42.8 \mathrm{~g} \mathrm{~kg}^{-1}(n=39)$.

More than $50 \%$ of sewage sludge is applied to land for disposal [6], and sludge is often considered for use on farmland to supply $\mathrm{N}$ for crops [7-10]. N-release varies both within and among sludge materials. Between 4 and $48 \%$ of organic $\mathrm{N}$ was mineralized from anaerobically digested municipal sewage sludge in a soil incubation lasting 16 weeks [11]. Similarly, between $0 \%$ and $59 \%$ of organic $\mathrm{N}$ was mineralized over 58-74 days of incubation with soil in the laboratory for
16 municipal sludges [5]. Field trials also show variability. In the first year after application, $55 \%$ of organic $\mathrm{N}$ in liquid sludge from secondary municipal sewage treatment was mineralized in fields of corn (Zea mays L.) and hay [12]. In one season, $16 \%$ of applied $\mathrm{N}$ in the form of swine lagoon sludge was recovered in grass harvested, with $24 \%$ recovered from municipal sludge in a similar trial [13]. Sludge from lagoon sources was also found elsewhere to have less plant-available $\mathrm{N}$ than sludge from nonlagoon sources [14]. Residual effects of sludge application are also possible [2]. Nitrification in sludge is often pronounced $[15,16]$ and can lead to delivery of nitrate to $75 \mathrm{~cm}$ depth within a single season [17].

The sludge investigated here was prepared by dewatering of textile manufacturing wastewater that changed total solids to $43 \%$ by mass, corresponding to $1.32 \mathrm{~g} \mathrm{H}_{2} \mathrm{O} \mathrm{g}^{-1}$ dry mass of sludge cake. Extraction of water from sewage sludge is expected to remove much of the mineral N, so that knowledge of the rate of $\mathrm{N}$ mineralization from this sludge was needed in addition to data for mineral $\mathrm{N}$ in order to evaluate sludge utility for land application. Leachate of saponin secondary metabolites from alfalfa roots can inhibit nitrification 
[18]. If similar inhibition is caused by alfalfa shoot, then, compared to alfalfa, sludge may offer an alternative solidform organic source of $\mathrm{N}$ without such inhibition.

The first aim of this study was to determine $\mathrm{N}$ mineralization from textile manufacturing wastewater sludge to evaluate possible use of the material to offset crop $\mathrm{N}$ demand. To further explore nitrification inhibition for mineralized ammonium, experimental comparison to alfalfa shoot amendment was undertaken in parallel soil incubations. A second aim of this study was to predict mineralization of sludge cake when applied as coarse material. For this objective, a separate incubation experiment was undertaken to investigate of the impact of particle size of the sludge cake on $\mathrm{N}$ mineralization. The third aim of the study was to compare availability for crop uptake of $\mathrm{N}$ from the sludge to that of inorganic $\mathrm{N}$ fertilizer. To this end, a greenhouse experiment was conducted with sludge application to soil that was then sown to corn with separate corn pots receiving only $\mathrm{NH}_{4} \mathrm{NO}_{3}$ fertilizer.

\section{Materials and Methods}

2.1. Collection of Materials. Conostogo silt loam soil was collected for use in incubation and greenhouse experiments from the top $15 \mathrm{~cm}$ of the profile of low- $\mathrm{N}$ fertility plots at the Elora Research Station at $43^{\circ} 41^{\prime} \mathrm{N}$ and $80^{\circ} 14^{\prime} \mathrm{W}$ in Ontario, Canada. To minimize $\mathrm{N}$ availability, the field soil had been cropped to barley without $\mathrm{N}$ fertilizer in the previous year. This soil is mapped as a gleyed melanic brunisol within the Canadian system of soil classification [19], with $300 \mathrm{~g}$

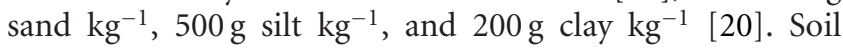
was partially air-dried, passed through a $5 \mathrm{~mm}$ screen, and stored in polythene bags until use. Using standard forage management for the region, alfalfa tops were collected from plots at the Elora Research Station, dried at $70^{\circ} \mathrm{C}$, and ground to pass a $2 \mathrm{~mm}$ screen. Alfalfa shoot had $29.5 \mathrm{mg} \mathrm{N} \mathrm{g}^{-1}$ dry mass. Sludge was supplied as a dewatered cake from the sewage treatment plant of Du Pont Canada Inc. at Maitland, ON, Canada. Wastewater from textile manufacture generates this sewage sludge at the DuPont installation. The wastewater sludge was prepared at the Maitland site of textile manufacture from a well-mixed aerobic wastewater treatment lagoon. The sludge cake was prepared by partial water removal by application of physical pressure following bulking with $\mathrm{FeCl}_{3}$. The sludge retained $1.32 \mathrm{~g} \mathrm{H}_{2} \mathrm{Og}^{-1}$ dry mass when delivered by refrigerated truck for study and was kept in polythene bags to stabilize this moisture level until use.

2.2. Analysis of Soil and Amendments. While at the moisture level as supplied, the sludge was passed through a $2 \mathrm{~mm}$ sieve prior to all analyses. Moisture contents of sludge and soil were determined by drying to constant mass at $105^{\circ} \mathrm{C}$. Total $\mathrm{N}$ and $\mathrm{C}$ for amendments were determined by combustion using a Leco FP-428 furnace. Sludge and soil samples were extracted in $2.0 \mathrm{M} \mathrm{KCl}$ with a $5: 1$ ratio of extracting solution to sludge or soil for mineral $\mathrm{N}$ determination. Ammonium and nitrate concentrations in extracts were determined spectrophotometrically using a standard autoanalysis system
[21]. Elemental analysis of the textile wastewater sludge was determined for triplicate $0.5 \mathrm{~g}$ samples that were heated in $5 \mathrm{~mL} \mathrm{65 \%} \mathrm{nitric} \mathrm{acid} \mathrm{in} \mathrm{the} \mathrm{following} \mathrm{microwave} \mathrm{sequence:} 5$ minutes at $250 \mathrm{~W}, 1$ minute at $0 \mathrm{~W}, 4$ minutes at $250 \mathrm{~W}$, and 7 minutes at $400 \mathrm{~W}$. Leachate was filtered using Whatman no. 42 paper and brought to a final volume of $100 \mathrm{~mL}$ using ultrafiltration-purified water. Elemental composition of the sludge was determined by analysis of leachate using ICP optical atomic emission spectrometry (ICP-OES) at the Ministry of Northern Development of Mines, Sudbury, ON, Canada.

2.3. Incubation Experiment One. Sludge was passed moist through a $2 \mathrm{~mm}$ sieve and incubated in glass Mason jars with screw caps tightly sealed and jars placed in the dark for 28 days at $25^{\circ} \mathrm{C}$ and $0.23 \mathrm{~g} \mathrm{H}_{2} \mathrm{O} \mathrm{g}^{-1}$ dry soil at rates of 100,200 , 400 , and $800 \mathrm{mg} \mathrm{N} \mathrm{kg}^{-1}$ dry soil. All jars were mixed immediately following amendment on the day of setup. As well as controls, amendments of alfalfa shoot at the same rates of $\mathrm{N}$ addition gave nine amendment treatments. There were four replicates for each combination of amendment and time, giving 216 incubations in all. Available ammonium and nitrate were determined as described above for separate incubations on the day of setup and after 1, 4, 7, 14, and 28 days of incubation. Prior to harvest of each jar, headspace was sampled by gas syringe through a rubber port in the jar lid. Concentrations of $\mathrm{CO}_{2}$ were determined for syringe samples using a Gow Mac gas chromatograph with infrared detector.

2.4. Incubation Experiment Two. Mineralization of inorganic $\mathrm{N}$ from moist sludge fractions able to pass $2 \mathrm{~mm}, 4 \mathrm{~mm}$, and $9.5 \mathrm{~mm}$ screens was assessed, giving three amendment treatments. Screen fractions and the nonsieved sludge were applied at $400 \mathrm{mg} \mathrm{N} \mathrm{kg}^{-1}$ dry soil and compared to controls with no sludge added. There were four replicates of each treatment combination of amendment and time, giving 48 incubation units in all. Incubations were maintained at room temperature and $0.23 \mathrm{~g} \mathrm{H}_{2} \mathrm{O} \mathrm{g}^{-1}$ dry soil in Mason jars in the dark. Ammonium and nitrate mineralized was determined as above for separate incubations immediately after setup and after 4 and 14 days of incubation.

2.5. Greenhouse Experiment. Sludge was passed moist through a $2 \mathrm{~mm}$ sieve before use. Soil was mixed with sludge at 100,200 , and $400 \mathrm{mg} \mathrm{N} \mathrm{kg}^{-1}$ dry soil. As well as controls, $\mathrm{NH}_{4} \mathrm{NO}_{3}$ fertilizer was mixed with soil in separate incubations at rates of 25,50 , and $75 \mathrm{mg} \mathrm{N} \mathrm{kg}^{-1}$ dry soil, which gave seven treatments in all. There were four replicates of each treatment, giving a total of $2820-\mathrm{cm}$ diameter pots. Maize was grown for 24 days from presoaked seed in pots in the greenhouse. Six seeds were sown per pot, with thinning to four seedlings per pot after one week. Pots were watered daily to gravimetrically maintain $0.23 \mathrm{~g} \mathrm{H}_{2} \mathrm{O} \mathrm{g}^{-1}$ dry soil. Plants were at the six- or seven-leaf stage at harvest. Shoots were removed by cutting $5 \mathrm{~mm}$ above the soil surface at harvest and dried at $70^{\circ} \mathrm{C}$. Two $33 \mathrm{~mm}$ soil cores were then taken from each pot approximately mid-way between shoot bases, about half the distance from the center to the edge of the pot, and to the full pot depth. One core was selected at random 
TABLE 1: Comparison of determinations for the textile wastewater sludge $(n=4)$ to wastewater sludge materials $(n=17)$ reported [24] for analyses on a dry-mass basis for total C and N, C/N ratio, ammonium-N, and nitrate-N; s.d. = standard deviation; n.d. = not determined.

\begin{tabular}{lccccc}
\hline \multirow{2}{*}{ Property } & \multirow{2}{*}{ Units } & \multicolumn{2}{c}{ Sludge in present study } & & \multicolumn{2}{c}{ Published data } \\
Mean & s.d. & Minimum & 12 & 100 \\
Total N & $\mathrm{g} \mathrm{kg}^{-1}$ & 40.0 & 5.0 & 175 & 531 \\
$\mathrm{C}$ & $\mathrm{g} \mathrm{kg}^{-1}$ & 261 & 1.2 & 5.3 & 18.8 \\
$\mathrm{C} / \mathrm{N}$ ratio & none & 6.6 & 0.04 & 0 & 290 \\
$\mathrm{NH}_{4}-\mathrm{N}$ & $\mathrm{g} \mathrm{kg}^{-1}$ & $1.49^{\mathrm{a}}$ & 0.003 & n.d. & nedian \\
$\mathrm{NO}_{3}-\mathrm{N}$ & $\mathrm{g} \mathrm{kg}^{-1}$ & $0.020^{\mathrm{a}}$ & & & n.d. \\
\hline
\end{tabular}

${ }^{\mathrm{a}} 2.0 \mathrm{M} \mathrm{KCl}$ with $5: 1$ extract-to-sludge ratio.

b $1.0 \mathrm{M} \mathrm{KCl}$ with $100: 1$ extract-to-sludge ratio.

from each pot and used to wash roots on a $0.1 \mathrm{~mm}$ screen. Roots were then scored for root length [22] and dried at $70^{\circ} \mathrm{C}$. Dried shoot and root was analyzed for total $\mathrm{N}$ by combustion as above. The soil from the second core from each pot was sieved on a $2 \mathrm{~mm}$ screen, discarding roots, stones, and organic debris. This sieved soil was used for analysis of total $\mathrm{N}$ and levels of ammonium and nitrate as above.

2.6. Statistical Design and Analysis. All experiments were arranged in a randomized complete block design with random arrangement of treatments within a block. Treatment effects were investigated using analyses of variance with separation of means using the Tukey system [23]. Comparison of rates of $\mathrm{CO}_{2}$ production between incubations with amendments of sludge and alfalfa was made by the Wilcoxon nonparametric test [23] for samples paired according to rate of $\mathrm{N}$ addition and time of sample analysis.

\section{Results}

Analyses of 17 sludge materials [24] were compared to the textile wastewater sludge (Table 1). The textile wastewater sludge was found to be moderate, in terms of similarity to median values among the 17 sludge materials from the literature, for total $\mathrm{N}$, total $\mathrm{C}, \mathrm{C} / \mathrm{N}$ ratio, and $\mathrm{KCl}$-extractable $\mathrm{NH}_{4}-\mathrm{N}$ (Table 1). Compared to the alfalfa amendment of $29.5 \mathrm{mg} \mathrm{N} \mathrm{g}^{-1}$, for which all $\mathrm{N}$ was assumed to be in organic combination, the sludge contained $1.5 \mathrm{~g} \mathrm{NH}_{4}-\mathrm{N} \mathrm{kg}^{-1}$ and $40 \mathrm{~g} \mathrm{~N} \mathrm{~kg}^{-1}$ (Table 1) so that approximately $4 \%$ of $\mathrm{N}$ in the sludge was in the form of ammonium. The sludge was similar in elemental composition to municipal sludge (Table 2) although $\mathrm{Mn}$ at $838 \mathrm{mg} \mathrm{kg}^{-1}$ dry mass and B at $498 \mathrm{mg} \mathrm{kg}^{-1}$ dry mass were 2- and 6-times greater, respectively, than the concentration means for a wide range of sludges from earlier survey [4]. However, these values for Mn and B for the textile wastewater sludge were still within the wide ranges of concentrations in municipal sludges for these elements [4]. More recent data also show wide variability in concentration of $\mathrm{B}$ and Mn. Environmental Protection Agency sewage sludge analyses fell in the range $6-204 \mathrm{mg} \mathrm{kg}^{-1}$ for B with $n=80$ and in the range $35-14.900 \mathrm{mg} \mathrm{kg}^{-1}$ for Mn with $n=84$ [25].

3.1. Incubation Experiment One. Ammonium (Figure 1) and nitrate (Figure 2) were released from both the sludge and
TABLE 2: Concentration in the sludge of the 20 elements exceeding $10 \mathrm{mg} \mathrm{kg}^{-1}$ in addition to $\mathrm{C}, \mathrm{H}, \mathrm{O}, \mathrm{N}, \mathrm{K}$, and $\mathrm{S}$. Means and standard deviations (s.d.) are for $n=3$.

\begin{tabular}{lcc}
\hline Element & Mean & s.d. \\
\hline $\mathrm{Fe}$ & \multicolumn{2}{c}{$\mathrm{mg} \mathrm{kg}^{-1}$ dry mass } \\
$\mathrm{P}$ & 5214 & 279 \\
$\mathrm{Ca}$ & 3544 & 380 \\
$\mathrm{Mg}$ & 1538 & 474 \\
$\mathrm{Cu}$ & 1004 & 250 \\
$\mathrm{Mn}$ & 838 & 43 \\
$\mathrm{Al}$ & 711 & 143 \\
$\mathrm{~B}$ & 498 & 15 \\
$\mathrm{Ti}$ & 190 & 79 \\
$\mathrm{Zn}$ & 129 & 14 \\
$\mathrm{~V}$ & 117 & 16 \\
$\mathrm{Cr}$ & 101 & 3 \\
$\mathrm{Ni}$ & 70 & 11 \\
$\mathrm{Zr}$ & 40 & 8 \\
$\mathrm{Ba}$ & 40 & 7 \\
$\mathrm{~Pb}$ & 31 & 6 \\
$\mathrm{Ta}$ & 26 & 11 \\
$\mathrm{Sr}$ & 22 & 23 \\
$\mathrm{As}$ & 13 & 2 \\
$\mathrm{Co}$ & 13 & 15 \\
\hline & & 1 \\
\hline
\end{tabular}

from the alfalfa over the period of incubation. Almost all mineral-N in the sludge treatments was in the form of nitrate at 28 days (Figures 1 and 2), indicating that the sludge did not interfere with nitrification. In contrast, ammonium accumulated transiently for the $400 \mathrm{mg} \mathrm{N} \mathrm{kg}^{-1}$ alfalfa treatment (Figure 1(c)) and persistently following alfalfa addition at the $800 \mathrm{mg} \mathrm{N} \mathrm{kg}^{-1}$ level (Figure 1(d)), indicating that nitrification was inhibited by these higher rates of alfalfa amendment. Where mineral $\mathrm{N}$ is the sum of ammonium and nitrate forms, the slope of the regression for mineral $\mathrm{N}$ released after subtracting controls, as a function of $\mathrm{N}$ added, was 0.20 (Figure 3). This slope indicates that on average, $20 \%$ of added $\mathrm{N}$ was recovered as mineral $\mathrm{N}$ after 28 days of the experiment, irrespective of whether the addition was in the form of alfalfa or sludge. 


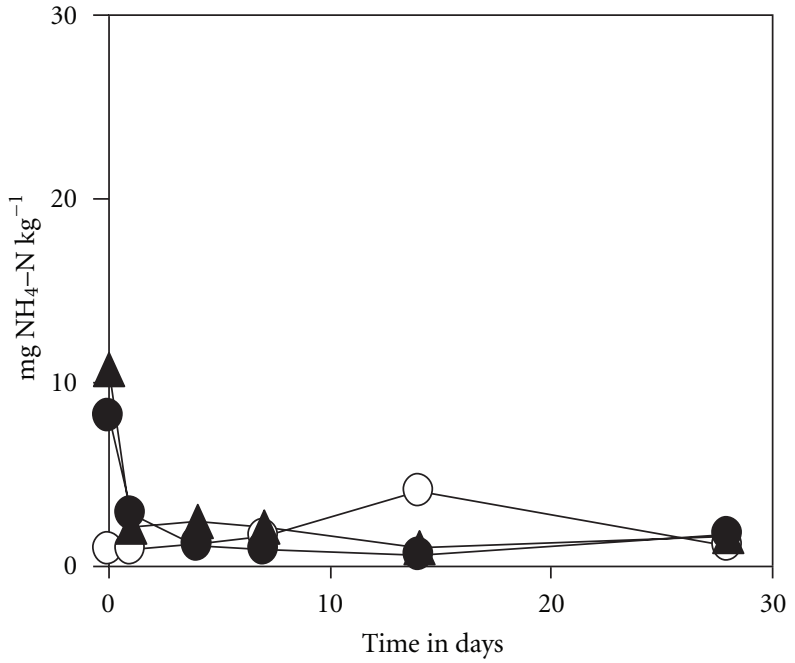

(a)

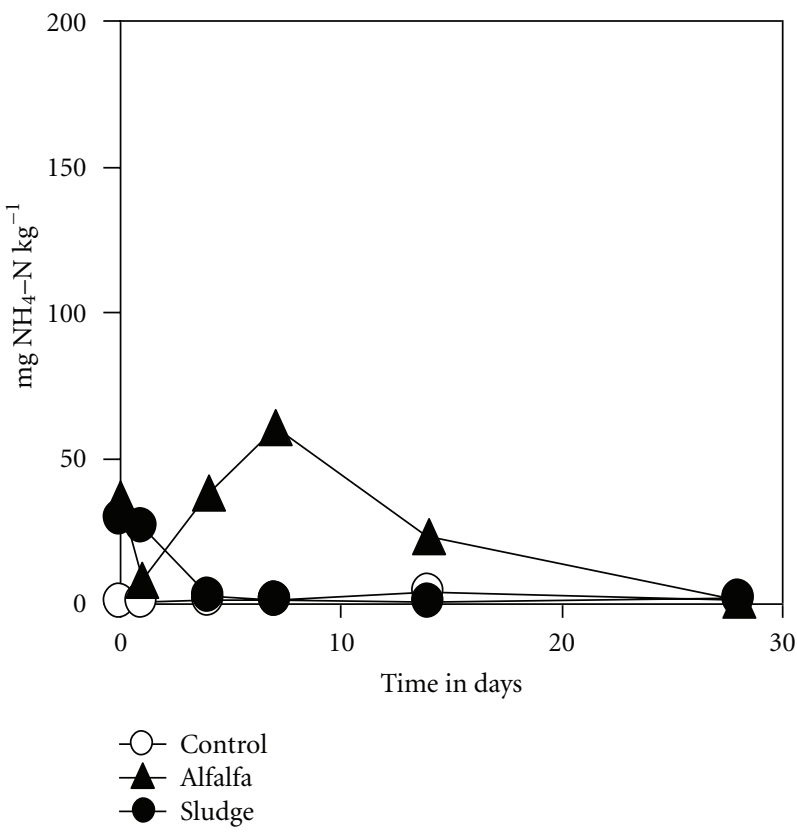

(c)

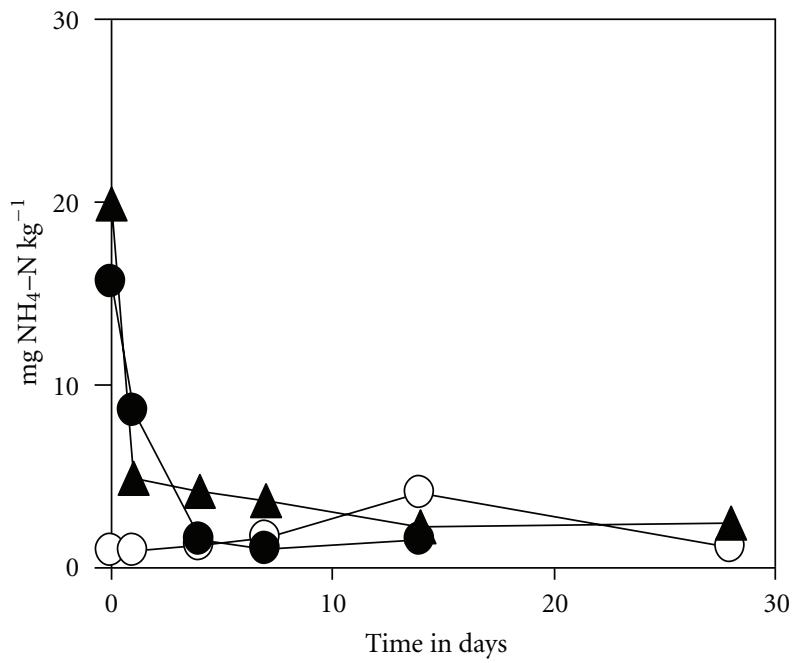

(b)

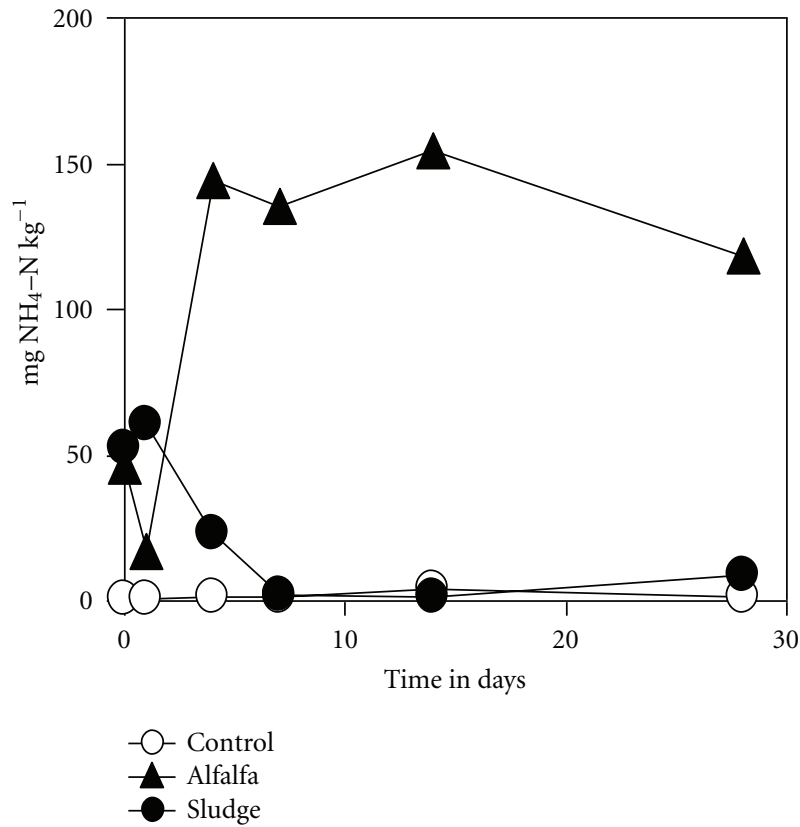

(d)

FIGURE 1: Incubation experiment one. Changes with time for ammonium extracted from incubations of sludge and alfalfa with soil at rates of (a) 100, (b) 200, (c) 400, and (d) $800 \mathrm{mg} \mathrm{N} \mathrm{kg}^{-1}$ dry soil. Controls received no amendment.

A pulse of $\mathrm{CO}_{2}$ production with maximum after four days was seen for the highest rate of alfalfa addition, whereas $\mathrm{CO}_{2}$ release from the $200 \mathrm{mg} \mathrm{N} \mathrm{kg}^{-1}$ and $400 \mathrm{mg} \mathrm{N} \mathrm{kg}^{-1}$ alfalfa treatments were highest after one day (Figure 4(a)). Rates of $\mathrm{CO}_{2}$ released from the sludge incubations (Figure 4(b)) were lower $(P=0.002)$ than for the corresponding alfalfa treatments (Figure 4(a)) for most combinations of amendment rate and time of sampling.

3.2. Incubation Experiment Two. Sieving the sludge did not affect nitrogen mineralization, with similar low values for ammonium and similar values for increased nitrate, relative to controls, for all screen sizes at both 4 and 14 days (Table 3 ).
A decreased level of ammonium for the two finest screen sizes immediately after setup, relative to the coarsest screen (Table 3), was likely caused by more ammonium diffusion to smaller particle surfaces and gaseous losses from the more finely screened material.

3.3. Greenhouse Experiment. Plants in all treatments were developmentally advanced by one leaf stage over controls $(P<$ 0.001 ), with 5.9 leaves plant ${ }^{-1}$ for controls, and means ranging from 6.8 to 7.0 leaves plant ${ }^{-1}$ for the other treatments. No negative impact of sludge treatment was evident on inspection of the plants in this study. Ammonium nitrate fertilization and sludge amendment both caused shoot growth 


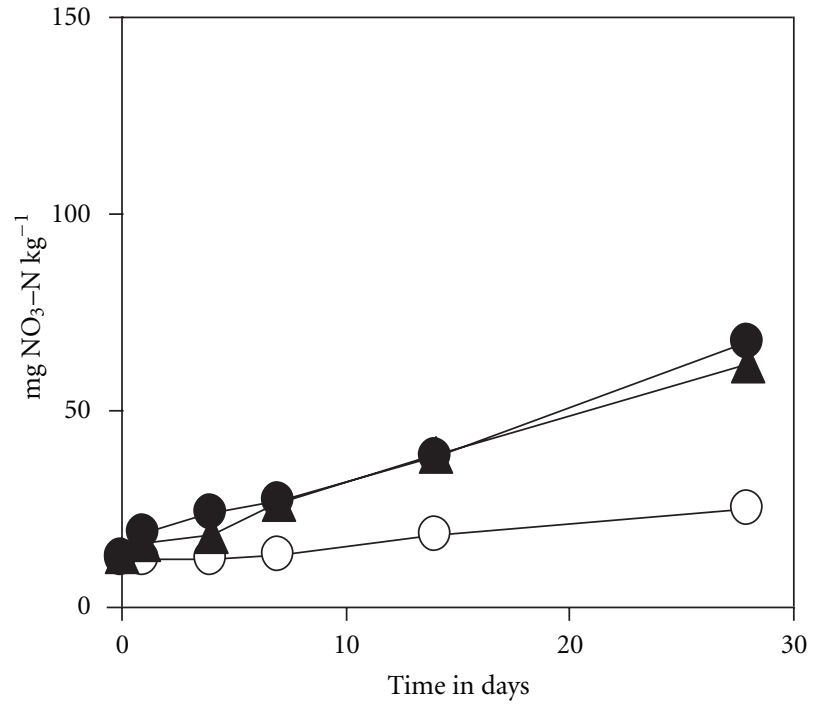

(a)

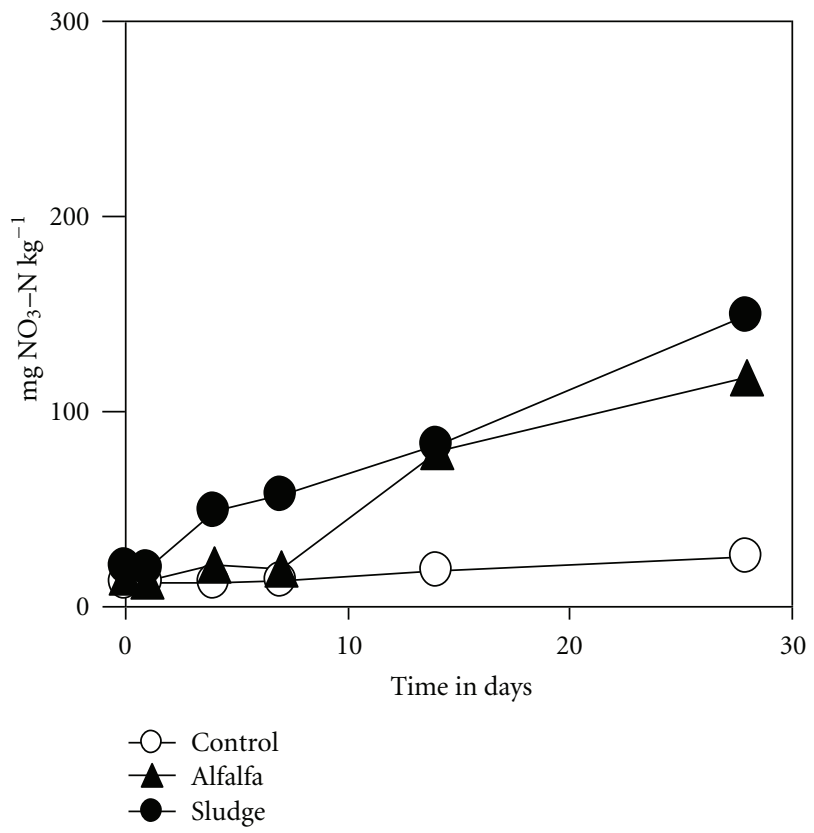

(c)

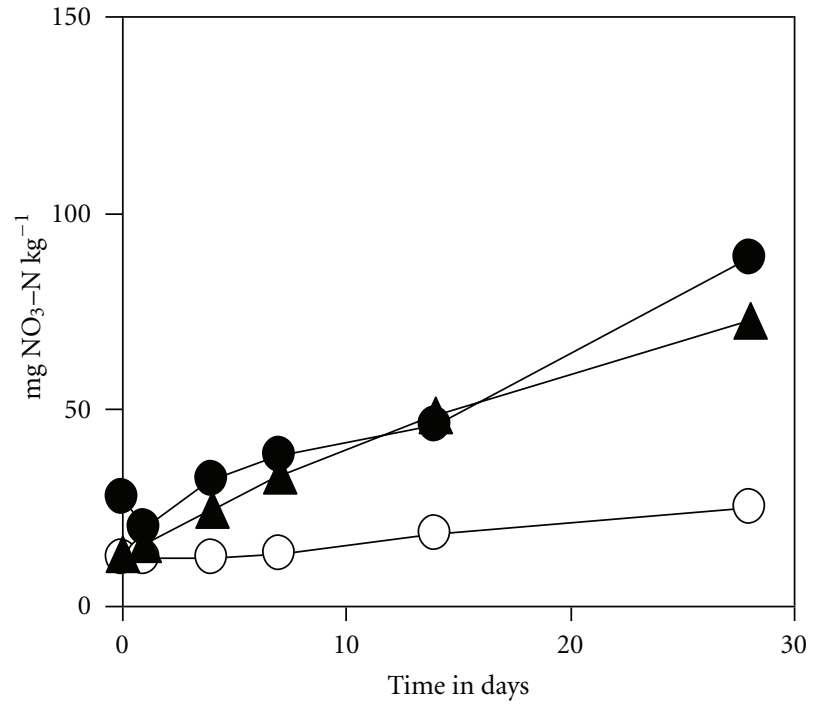

(b)

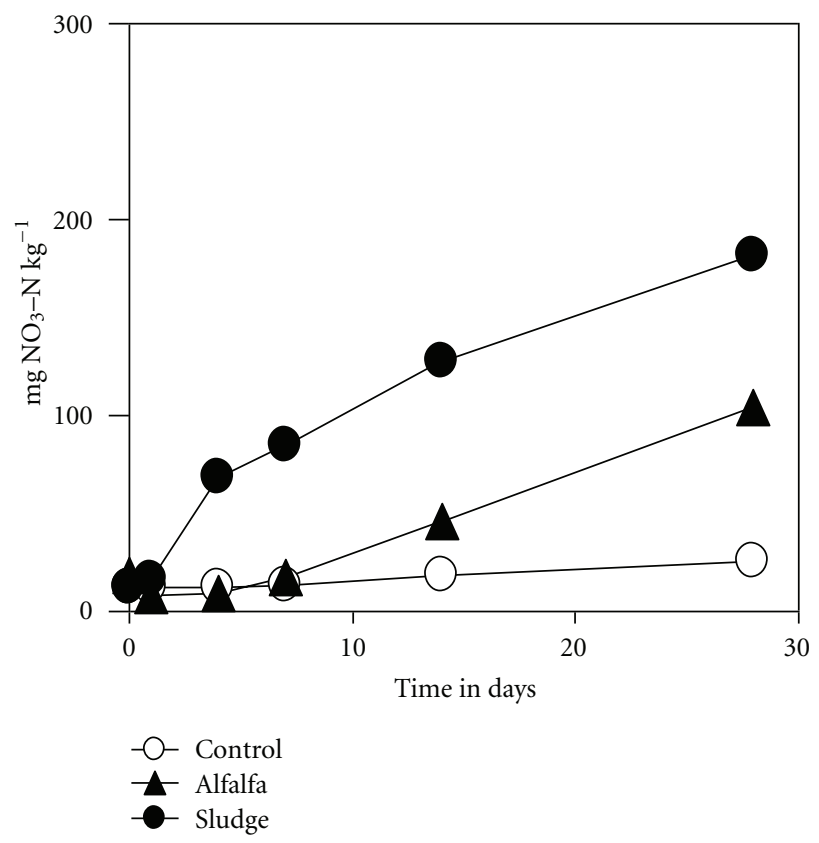

(d)

Figure 2: Incubation experiment one. Changes with time for nitrate extracted from incubations of sludge and alfalfa with soil at rates of (a) 100, (b) 200, (c) 400, and (d) $800 \mathrm{mg} \mathrm{N} \mathrm{kg}^{-1}$ dry soil. Controls received no amendment.

responses $(P<0.001)$ as determined at 24 days (Figure 5(a)). Shoot $\mathrm{N}$ concentration responded in a stepwise manner to increments of fertilizer and sludge treatment (Figure 5(b)). Shoot $\mathrm{N}$ concentration in control pots was markedly deficient at $15.4 \mathrm{mg} \mathrm{g}^{-1}$ but increased to as high as $49.1 \mathrm{mg} \mathrm{g}^{-1}$ and $40.9 \mathrm{mg} \mathrm{g}^{-1}$ with the highest rates of addition of sludge and fertilizer, respectively (Figure 5(b)). Root length density was significantly $(P=0.03)$ greater for plants with the lowest amendment of sludge compared to those with the lowest amendment of ammonium nitrate, but no amended treatment was different from the control (Figure 5(c)). Root mass density $(P=0.07)$ was similar among treatments, with overall mean \pm standard deviation $=0.36 \pm 0.08 \mathrm{~g}$ root $\mathrm{L}^{-1}$ soil for $n=28$. Specific root length $(P=0.11)$ was also similar among treatments, with overall mean \pm standard deviation $=10.4 \pm 2.9 \mathrm{~cm}$ root $\mathrm{mg}^{-1}$ root for $n=28$. Root $\mathrm{N}$ concentration increased from $9.9 \mathrm{mg} \mathrm{g}^{-1}$ in controls to as high as $24.8 \mathrm{mg} \mathrm{g}^{-1}$ and $20.5 \mathrm{mg} \mathrm{g}^{-1}$ with the highest rates of addition of sludge and fertilizer, respectively (Figure 5(d)).

Ammonium in $\mathrm{NH}_{4} \mathrm{NO}_{3}$ fertilized soil did not differ from controls at harvest, but soil ammonium did increase in a stepwise manner (Figure 6(a)) in response to sludge amendment. Despite these differences among treatments, the concentrations of ammonium in soil at harvest were low in 


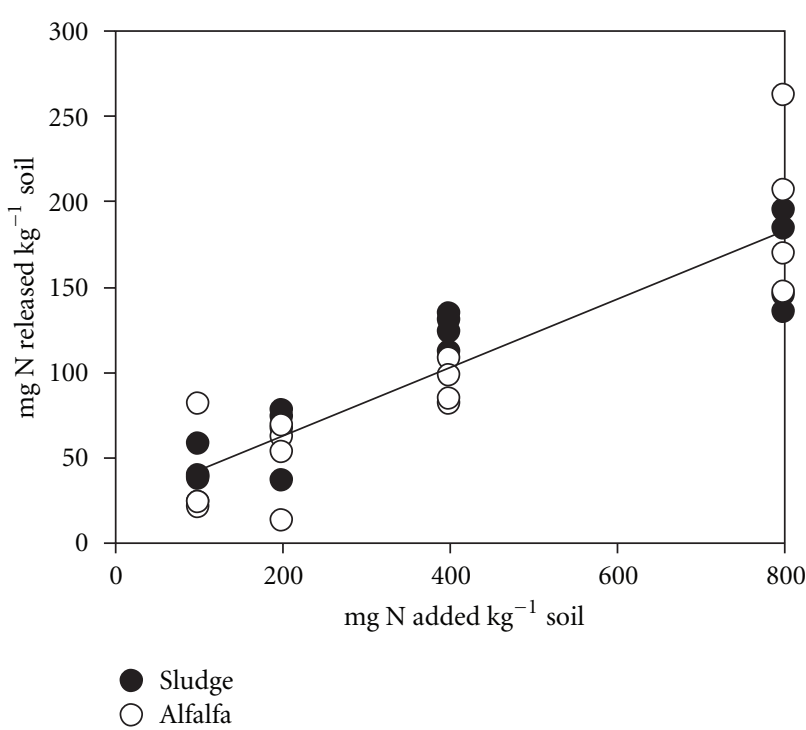

FIGURE 3: Incubation experiment one. Relation of $\mathrm{N}$ added to total mineral $\mathrm{N}$ released after 28 days for incubations of sludge and alfalfa with soil calculated with subtraction of mineral $\mathrm{N}$ in control incubations. The fitted regression line $y=20.0+0.20 x$ of $r^{2}=$ 0.81 for the data pooled across sludge and alfalfa amendments is significant $(P<0.001)$.

TABle 3: Incubation experiment two. Ammonium-N and nitrate$\mathrm{N}$ mineralized from different screen fractions of sludge applied at $400 \mathrm{mg} \mathrm{N} \mathrm{kg}^{-1}$ dry soil, as compared to controls with no sludge added. Means in a column followed by different letters ( $a, b$, and c for $\mathrm{NH}_{4}-\mathrm{N} ; \mathrm{x}, \mathrm{y}$, and $\mathrm{z}$ for $\mathrm{NO}_{3}-\mathrm{N}$ ) are significantly different at the $5 \%$ probability level.

\begin{tabular}{lccc}
\hline Screen size $(\mathrm{mm})$ & \multicolumn{3}{c}{ Day } \\
& 0 & 4 & 14 \\
\hline \multirow{2}{*}{ Control } & \multicolumn{3}{c}{$\mathrm{mg} \mathrm{NH}_{4}-\mathrm{N} \mathrm{kg}^{-1}$ dry soil } \\
2 & $31.7 \mathrm{~b}$ & $0.1 \mathrm{a}$ & $0.2 \mathrm{a}$ \\
4 & $36.6 \mathrm{~b}$ & $8.7 \mathrm{a}$ & $0.6 \mathrm{a}$ \\
9.5 & $57.9 \mathrm{c}$ & $11.5 \mathrm{a}$ & $0.8 \mathrm{a}$ \\
\hline & & $\mathrm{mg} \mathrm{NO}_{3}-\mathrm{N} \mathrm{kg}^{-1} \mathrm{dry}$ & $0.8 \mathrm{a}$ \\
Control & $12.0 \mathrm{x}$ & $12.6 \mathrm{x}$ & $16.8 \mathrm{x}$ \\
2 & $12.1 \mathrm{x}$ & $52.6 \mathrm{y}$ & $85.9 \mathrm{z}$ \\
4 & $12.4 \mathrm{x}$ & $58.2 \mathrm{y}$ & $80.4 \mathrm{z}$ \\
9.5 & $11.7 \mathrm{x}$ & $49.6 \mathrm{y}$ & $79.5 \mathrm{z}$ \\
\hline
\end{tabular}

all treatments relative to plant demand and did not exceed $2.4 \mathrm{mg} \mathrm{kg}^{-1}$. Nitrate in soil was low relative to crop demand and less than $3 \mathrm{mg} \mathrm{kg}^{-1}$ in all treatments, with the exception that nitrate accumulated to $30.4 \mathrm{mg} \mathrm{kg}^{-1}$ in pots with the highest rate of sludge amendment (Figure 6(b)).

\section{Discussion}

The sludge cake from textile manufacturing wastewater that was studied here released mineral $\mathrm{N}$ in soil incubations and provided adequate $\mathrm{N}$ to support maize growth in soil in pots without signs of damage to the crop. Mineralization of $\mathrm{N}$ was indistinguishable to mineralization from alfalfa shoot. The $20 \%$ of organic $\mathrm{N}$ released as ammonium or nitrate from the sludge over 28 days indicated that mineralization rates for the textile wastewater sludge were similar to those known for municipal sludges. In the first year following application of anaerobically digested municipal sludge biosolids, $40 \%$ of organic $\mathrm{N}$ was recovered by a field crop of maize [26]. Further recoveries of $20 \%$ and $10 \%$ of organic $\mathrm{N}$ applied were estimated [26] for the second and third years, respectively. Slightly lower rates of recovery have been recorded elsewhere, with $50 \%$ of sludge $\mathrm{N}$ recovered cumulatively over four successive field crops following land application of anaerobically digested municipal liquid sludge [7]. With the same sludge material as used by [7], much of the release of mineral $\mathrm{N}$ from organic $\mathrm{N}$ in sludge occurred within three weeks following field amendment [8]. Thus, the mineralization of $20 \%$ of organic $\mathrm{N}$ from the textile wastewater sludge cake within 28 days compares well to municipal sludge in terms of initial rate of $\mathrm{N}$ release.

Although similar to alfalfa shoot as an $\mathrm{N}$ source, the sludge offered freedom from nitrification inhibition at the highest rates of application, whereas nitrification inhibition appeared to occur for higher rates of alfalfa amendment. Ammonium accumulated transiently in the $400 \mathrm{mg} \mathrm{N} \mathrm{kg}^{-1}$ alfalfa treatment and persistently in the $800 \mathrm{mg} \mathrm{N} \mathrm{kg}^{-1}$ alfalfa treatment. Nitrification inhibition has been attributed to glucosinolates in shoot material of Brassicaceae [27], but the polyphenols of wider occurrence among plants, such the Fabaceae, do not inhibit nitrification [28]. Saponins in alfalfa root exudates are thought to inhibit nitrification [18], and so, saponins are a likely explanation for the nitrification inhibitory activity of alfalfa shoot.

Respiration was lower in the sludge amendments compared to the alfalfa treatments. Less respiration in the sludge compared to the alfalfa treatments probably relates to reduced availability of carbon substrates in the sludge. Soil respiration data found here are in keeping with expected values, as follows. A base reference value of oxygen demand for soils can be taken as $20 \mathrm{~g} \mathrm{O}_{2} \mathrm{~m}^{-2}$ day $^{-1}$ [29]. Assuming $1: 1$ equivalency of $\mathrm{O}_{2}$ consumed to $\mathrm{CO}_{2}$ released, this oxygen demand converts to $1.6 \mathrm{mg} \mathrm{CO}_{2}-\mathrm{C} \mathrm{kg}^{-1} \mathrm{~h}^{-1}$ respired for a $15 \mathrm{~cm}$ depth of generalized field soil of bulk density $1.33 \mathrm{~g} \mathrm{~kg}^{-1}$. Control values in incubation experiment one ranged from $0.9-5.6 \mathrm{mg} \mathrm{CO}_{2}-\mathrm{C} \mathrm{kg}^{-1} \mathrm{~h}^{-1}$, with values following amendment varying widely but not exceeding $83.5 \mathrm{mg}$ $\mathrm{CO}_{2}-\mathrm{C} \mathrm{kg}^{-1} \mathrm{~h}^{-1}$.

Application of sludge cake to fields would likely be undertaken by manure spreader. Therefore, the impact of sludge particle size on reaction rates could, in theory, bring about differences between field responses and laboratory or greenhouse studies. However, the sieve-size experiment conducted here shows that at least over the range from $2 \mathrm{~mm}$ to $9.5 \mathrm{~mm}$ sludge particle diameter, cake size dimension has no influence on the reaction of the sludge with soil in terms of rate of nitrate released. Fine-screened fractions of sludge cake studied here lost ammonium relative to the coarsest fraction at incubation establishment, likely because of gaseous loss 


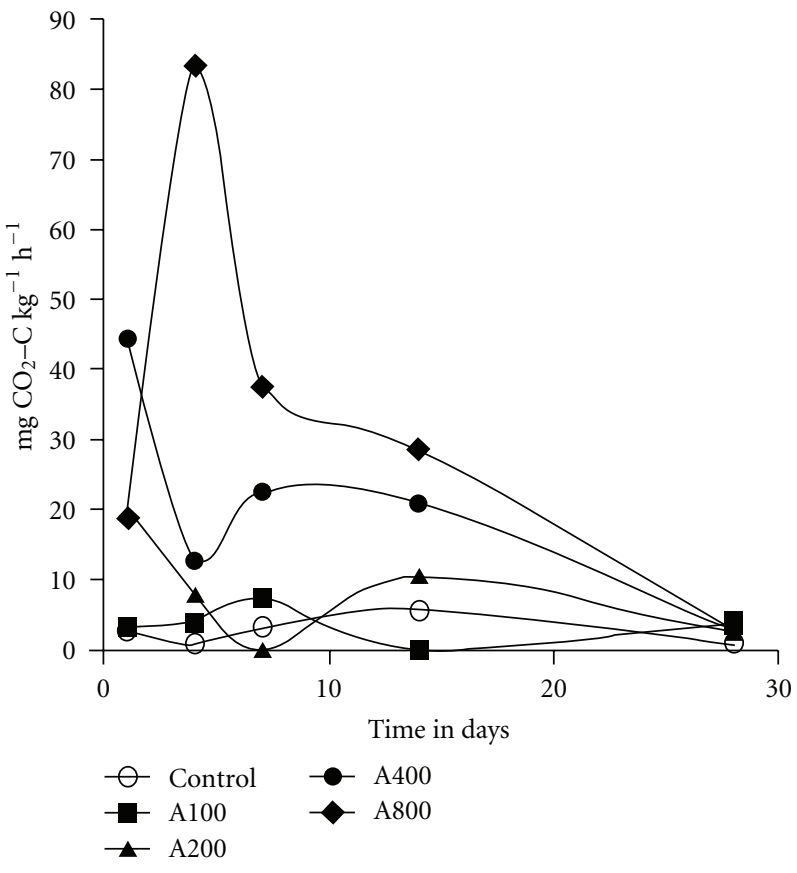

(a)

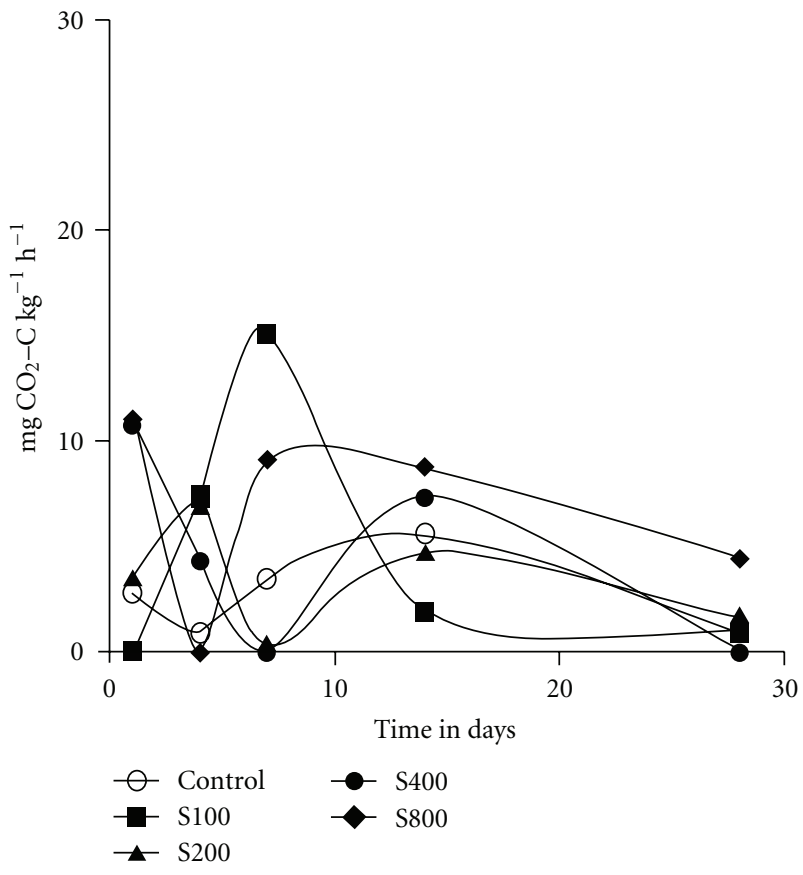

(b)

FIGURE 4: Incubation experiment one. Specific rates of carbon dioxide released from incubation of soil with (a) alfalfa and (b) sludge. Treatment codes refer to amendment rates of alfalfa (A100-A800) and sludge (S100-S800) added in the range $100-800 \mathrm{mg} \mathrm{N} \mathrm{kg}^{-1} \mathrm{dry} \mathrm{soil.}^{-}$

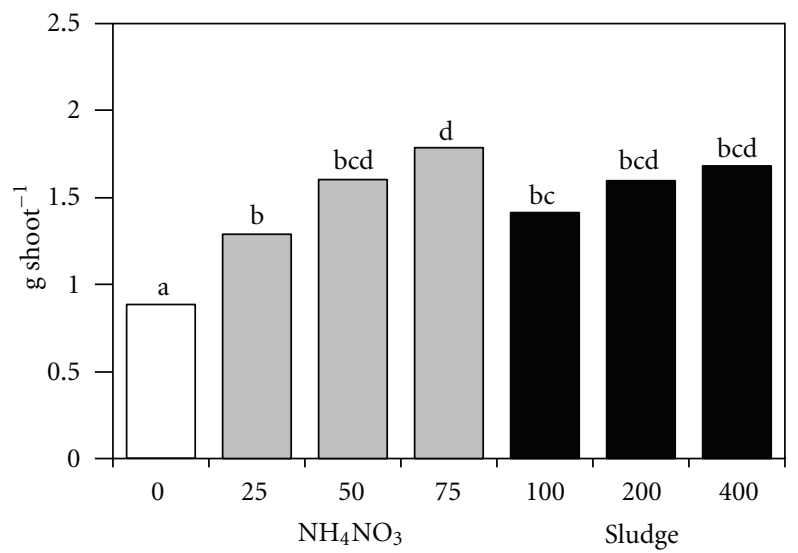

(a)

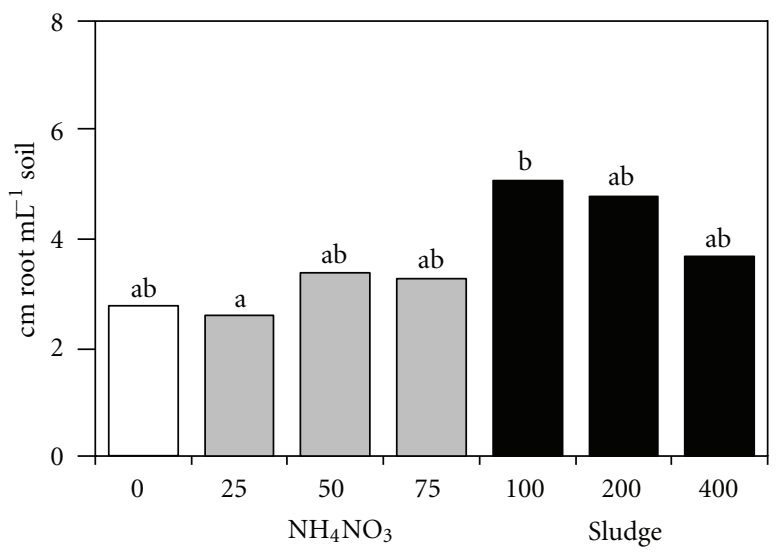

(c)

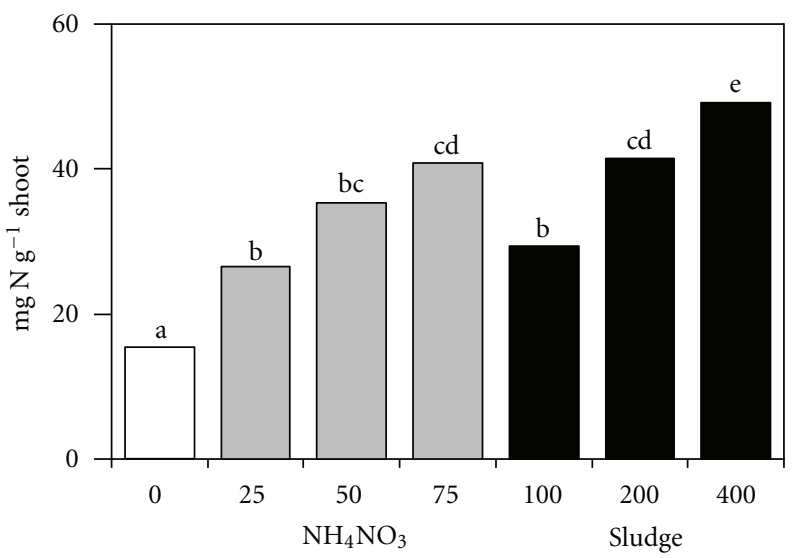

(b)

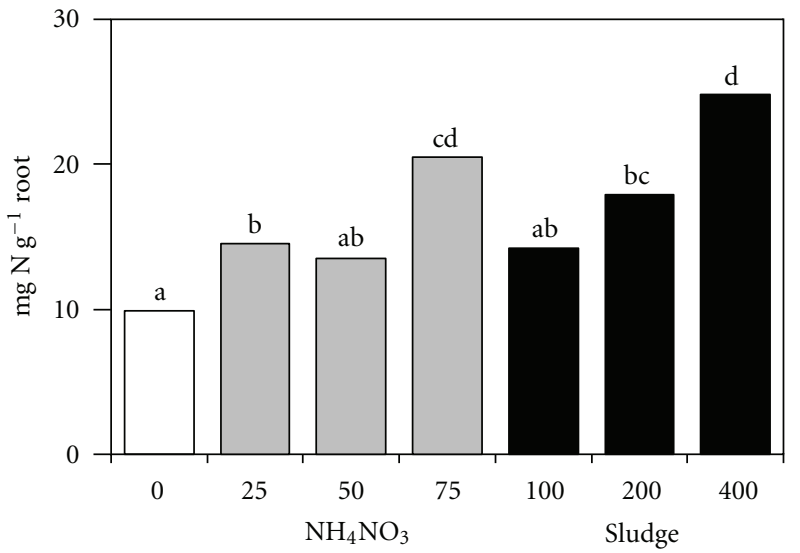

(d)

Figure 5: Greenhouse experiment. (a) Shoot dry mass, (b) shoot $\mathrm{N}$ concentration, (c) root length density, and (d) root N concentration

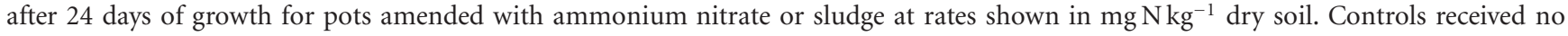
amendment. Means with different letters (a, b, c, d, and e) are significantly different at the $5 \%$ probability level. 


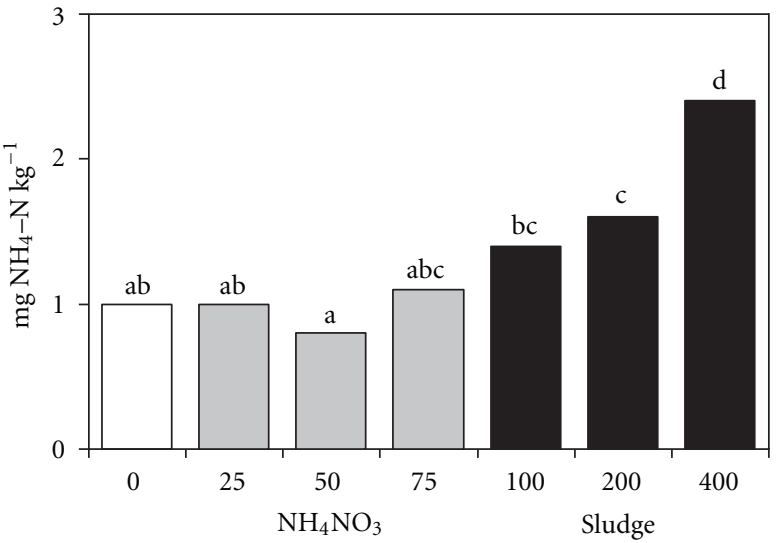

(a)

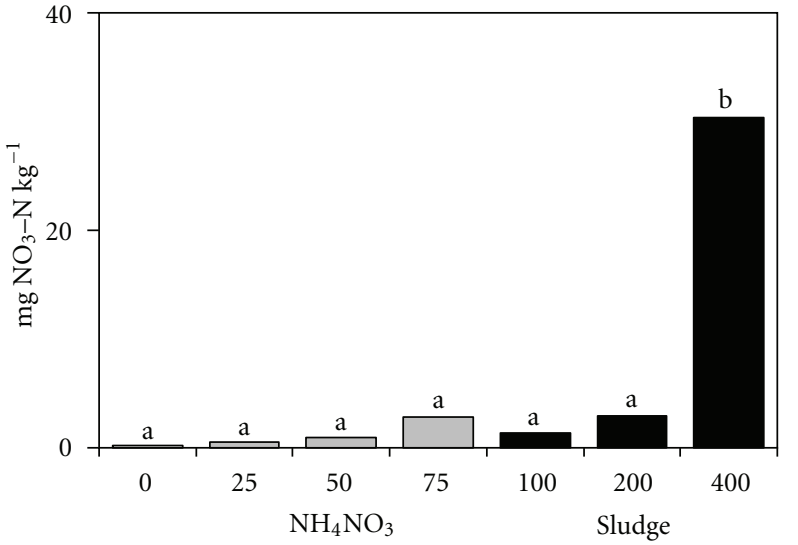

(b)

Figure 6: Greenhouse experiment. Soil ammonium-N and nitrate-N extracted from pots after 24 days of growth following amended with ammonium nitrate or sludge at rates shown in $\mathrm{mg} \mathrm{N} \mathrm{kg}^{-1}$ dry soil. Controls received no amendment. Means with different letters ( $\mathrm{a}$, b, $\mathrm{c}$, and d) are significantly different at the $5 \%$ probability level.

(Table 2). Use of coarse sludge cake material for land application, followed by incorporation where possible, would be expected to limit such gaseous loss of $\mathrm{N}$.

The $\mathrm{N}$ sufficiency range for maize during early growth is given as $35-50 \mathrm{mg} \mathrm{g}^{-1}$ [30]. Control treatment plants in the greenhouse experiment had $15 \mathrm{mg} \mathrm{g}^{-1}$ and were $\mathrm{N}$ deficient, and $\mathrm{N}$ concentrations of shoots across treatments ranged up to $50 \mathrm{mg} \mathrm{g}^{-1}$. The absence of a pronounced effect of fertilizer and sludge amendment on root growth, together with significant stimulation of shoot growth, was in keeping with established response patterns of increased shoot-to-root ratio following $\mathrm{N}$ addition [31]. Overall mean for root length density in the greenhouse study of $3.6 \mathrm{~cm} \mathrm{~cm}^{-3}$ was high compared to the season maximum of $2.0 \mathrm{~cm} \mathrm{~cm}^{-3}$ for maize in the field [32], but a relatively high root length density was not unexpected, given pot confinement. Specific root length of $10.4 \mathrm{~cm}$ root $\mathrm{mg}^{-1}$ root is slightly lower than values available for other grasses, but it is of the same order [33]. In contrast to fertilizer additions, however, the highest level of sludge amendment left residual soil nitrate in excess of that utilized by the crop. Sludge amendments at 100, 200 and $400 \mathrm{mg} \mathrm{N} \mathrm{kg}^{-1}$ were indistinguishable from $\mathrm{NH}_{4} \mathrm{NO}_{3}$ amendments at 25,50 , and $75 \mathrm{mg} \mathrm{N} \mathrm{kg}^{-1}$, respectively, in terms of values for shoot $\mathrm{N}$ uptake, which indicated that sludge $\mathrm{N}$ was approximately $25 \%$ as available as fertilizer $\mathrm{N}$.

\section{Acknowledgments}

Thanks to Karen Krywko and Nancy Dolbeck for technical assistance. This project was supported by research funds supplied by Third High Farms, RR no. 2, Iroquois, Ontario, Canada, KOE $1 \mathrm{~K} 0$.

\section{References}

[1] J. M. Walker, "Production, use and creative design of sewage sludge biosolids," in Sewage Sludge: Land Utilization and the Environment, C. E. Clapp, W. E. Larson, and R. H. Dowdy,
Eds., pp. 67-74, Soil Science Society of America, Madison, Wis, USA, 1994.

[2] Y. K. Soon, T. E. Bates, E. G. Beauchamp, and J. R. Moyer, "Land application of chemically treated sewage sludge: I. Effects on crop yield and nitrogen availability," Journal of Environmental Quality, vol. 7, no. 2, pp. 264-269, 1978.

[3] J. C. Barber and M. B. Moeller, "Incorporation of sewage sludge in commercial fertilizers," Industrial and Engineering Chemistry Product Research and Development, vol. 20, no. 3, pp. 409-413, 1981.

[4] L. E. Sommers, "Chemical composition of sewage sludges and analysis of their potential use as fertilizers," Journal of Environmental Quality, vol. 6, no. 2, pp. 225-232, 1977.

[5] J. T. Gilmour, C. G. Cogger, L. W. Jacobs, G. K. Evanylo, and D. M. Sullivan, "Decomposition and plant-available nitrogen in biosolids: laboratory studies, field studies, and computer simulation," Journal of Environmental Quality, vol. 32, no. 4, pp. 1498-1507, 2003.

[6] E. Epstein, Land Application of Sewage Sludge and Biosolids, CRC Press, Boca Raton, Fla, USA, 2003.

[7] K. A. Kelling, A. E. Peterson, L. M. Walsh, J. A. Ryan, and D. R. Keeney, "A field study of the agricultural use of sewage sludge: I. Effect on crop yield and uptake of N and P," Journal of Environmental Quality, vol. 6, no. 4, pp. 339-345, 1977.

[8] K. A. Kelling, L. M. Walsh, D. R. Keeney, J. A. Ryan, and A. E. Peterson, "A field study of the agricultural use of sewage sludge: II. Effect on soil N and P," Journal of Environmental Quality, vol. 6, no. 4, pp. 345-352, 1977.

[9] C. E. Clapp, R. H. Dowdy, D. R. Linden et al., "Crop yields, nutrient uptake, soil and water quality during 20 years on the Rosemount sewage sludge watershed," in Sewage Sludge: Land Utilization and the Environment, C. E. Clapp, W. E. Larson, and R. H. Dowdy, Eds., pp. 137-148, Soil Science Society of America, Madison, Wis, USA, 1994.

[10] K. A. Barbarick, J. A. Ippolito, and D. G. Westfall, "Distribution and mineralization of biosolids nitrogen applied to dryland wheat," Journal of Environmental Quality, vol. 25, no. 4, pp. 796-801, 1996.

[11] J. A. Ryan, D. R. Keeney, and L. M. Walsh, "Nitrogen transformations and availability of an anaerobically digested sewage 
sludge in soil," Journal of Environmental Quality, vol. 2, no. 4, pp. 489-492, 1973.

[12] F. R. Magdoff and J. F. Amadon, "Nitrogen availability from sewage sludge," Journal of Environmental Quality, vol. 9, no. 3, pp. $451-455,1980$.

[13] L. D. King, "Effect of swine manure lagoon sludge and municipal sewage sludge on growth, nitrogen recovery, and heavy metal content of fescuegrass," Journal of Environmental Quality, vol. 10, no. 4, pp. 465-472, 1981.

[14] C. G. Cogger, A. I. Bary, D. M. Sullivan, and E. A. Myhre, "Biosolids processing effects on first- and second-year available nitrogen," Soil Science Society of America Journal, vol. 68, no. 1, pp. 162-167, 2004.

[15] N. E. Stewart, C. T. Corke, E. G. Beauchamp, and L. R. Webber, "Nitrification of sewage sludge using miscible displacement and perfusion techniques," Canadian Journal of Soil Science, vol. 55, no. 4, pp. 467-472, 1975.

[16] E. G. Beauchamp, Y. K. Soon, and J. R. Moyer, "Nitrate production from chemically treated sewage sludges in soil," Journal of Environmental Quality, vol. 8, no. 4, pp. 557-560, 1979.

[17] N. E. Stewart, E. G. Beauchamp, C. T. Corke, and L. R. Webber, "Nitrate nitrogen distribution in corn land following applications of digested sewage sludge," Canadian Journal of Soil Science, vol. 55, pp. 287-294, 1975.

[18] Y. Leshem and I. Levin, "The effect of growing alfalfa on subseouent cotton plant development and on nitrate formation in peat soil," Plant and Soil, vol. 50, no. 1, pp. 323-328, 1978.

[19] C. Wagner-Riddle, G. W. Thurtell, E. G. Beauchamp, and R. Sweetman, "Estimates of nitrous oxide emissions from agricultural fields over 28 months," Canadian Journal of Soil Science, vol. 77, no. 2, pp. 135-144, 1997.

[20] J. W. Ketcheson, "Effect of tillage on fertilizer requirements for corn on a silt loam soil," Agronomy Journal, vol. 72, pp. 540$542,1980$.

[21] D. G. Maynard and Y. P. Kalra, "Nitrate and exchangeable ammonium nitrogen," in Soil Sampling and Methods of Analysis, M. R. Carter, Ed., pp. 25-38, Lewis, Boca Raton, Fla, USA, 1993.

[22] D. Tennant, "A test of a modified line intersect method of estimating root length," Journal of Ecology, vol. 63, pp. 9951001, 1975.

[23] J. H. Zar, Biostatistical Analysis, Prentice Hall, Upper Saddle River, NJ, USA, 5th edition, 2010.

[24] V. Parnaudeau, B. Nicolardot, and J. Pages, "Relevance of organic matter fractions as predictors of wastewater sludge mineralization in soil," Journal of Environmental Quality, vol. 33, no. 5, pp. 1885-1894, 2004.

[25] Environmental Protection Agency, "Targeted national sewage sludge survey sampling and analysis," Tech. Rep. EPA-822-R08-016, Environmental Protection Agency, Washington, DC, USA, 2009.

[26] D. L. Binder, A. Dobermann, D. H. Sander, and K. G. Cassman, "Biosolids as nitrogen source for irrigated maize and rainfed sorghum," Soil Science Society of America Journal, vol. 66, no. 2, pp. 531-543, 2002.

[27] G. D. Bending and S. D. Lincoln, "Inhibition of soil nitrifying bacteria communities and their activities by glucosinolate hydrolysis products," Soil Biology and Biochemistry, vol. 32, no. 8-9, pp. 1261-1269, 2000.

[28] K. Sivapalan, V. Fernando, and M. W. Thenabadu, "N-mineralization in polyphenol-rich plant residues and their effect on nitrification of applied ammonium sulphate," Soil Biology and Biochemistry, vol. 17, no. 4, pp. 547-551, 1985.
[29] K. Killham, Soil Ecology, Cambridge University Press, Cambridge, UK, 1994.

[30] J. B. Jones Jr., H. V. Eck, and R. Voss, "Plant analysis as an aid in fertilizing corn and grain sorghum," in Soil Testing and Plant Analysis, R. L. Westerman, Ed., pp. 521-547, Soil Science Society of America, Madison, Wis, USA, 3rd edition, 1990.

[31] E. L. Anderson, "Tillage and N fertilization effects on maize root growth and root: shoot ratio," Plant and Soil, vol. 108, no. 2, pp. 245-251, 1988.

[32] T. P. McGonigle and M. H. Miller, "Mycorrhizal development and phosphorus absorption in maize under conventional and reduced tillage," Soil Science Society of America Journal, vol. 57, no. 4, pp. 1002-1006, 1993.

[33] A. H. Fitter, "Functional significance of root morphology and root-system architecture," in Ecological Interactions in Soil, A. H. Fitter, D. Atkinson, D. J. Read, and M. B. Usher, Eds., pp. 87-106, Blackwell Scientific, Oxford, UK, 1985. 

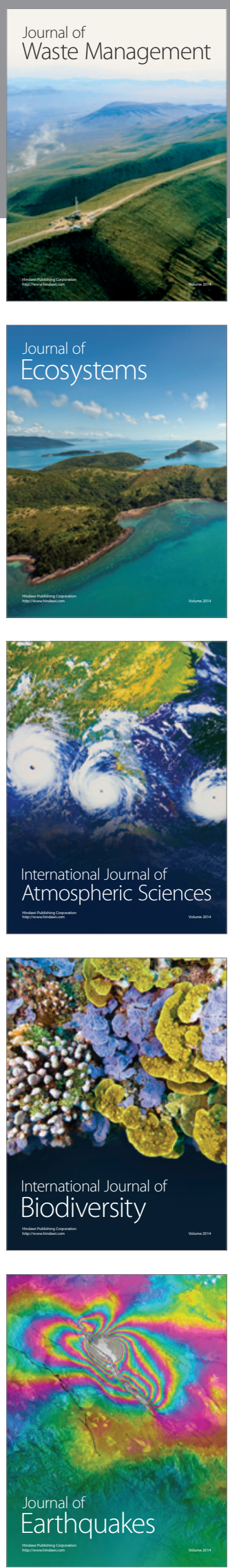
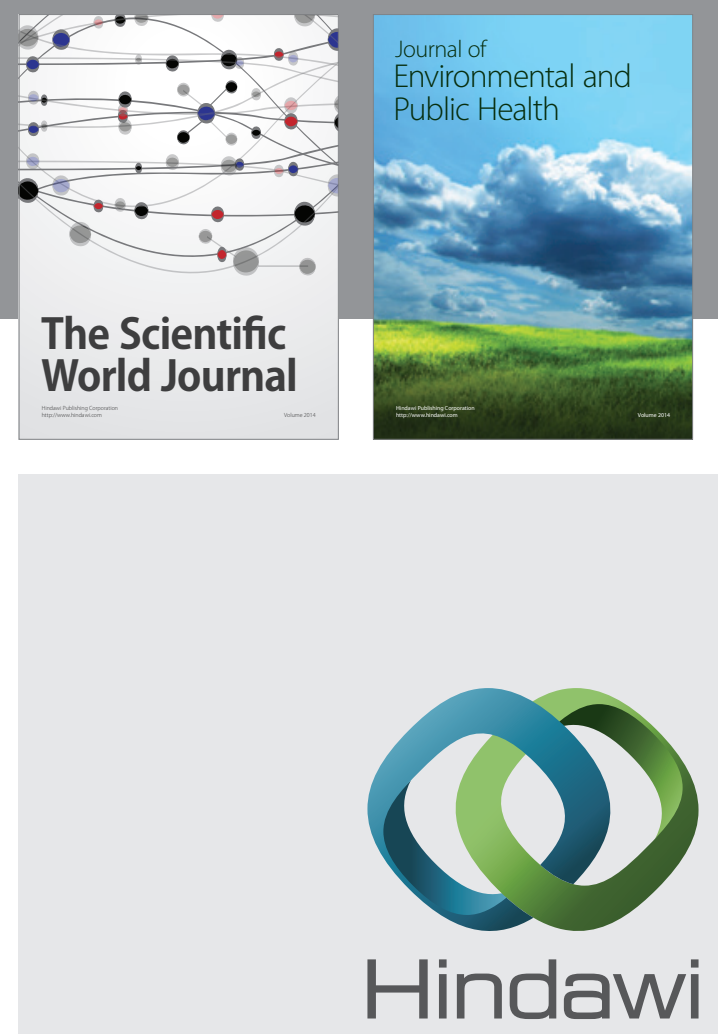

Submit your manuscripts at

http://www.hindawi.com
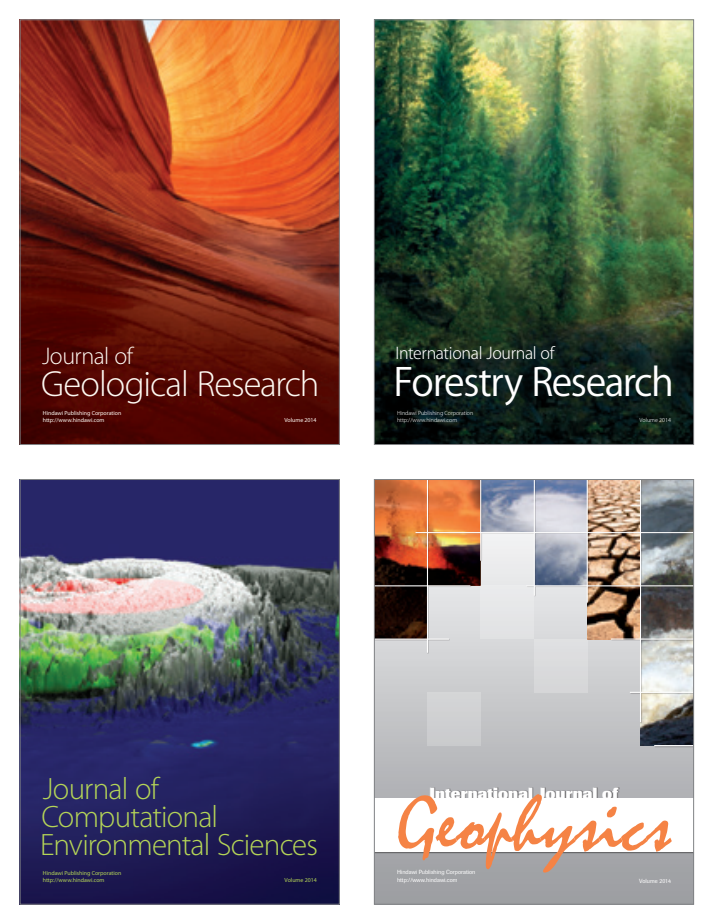
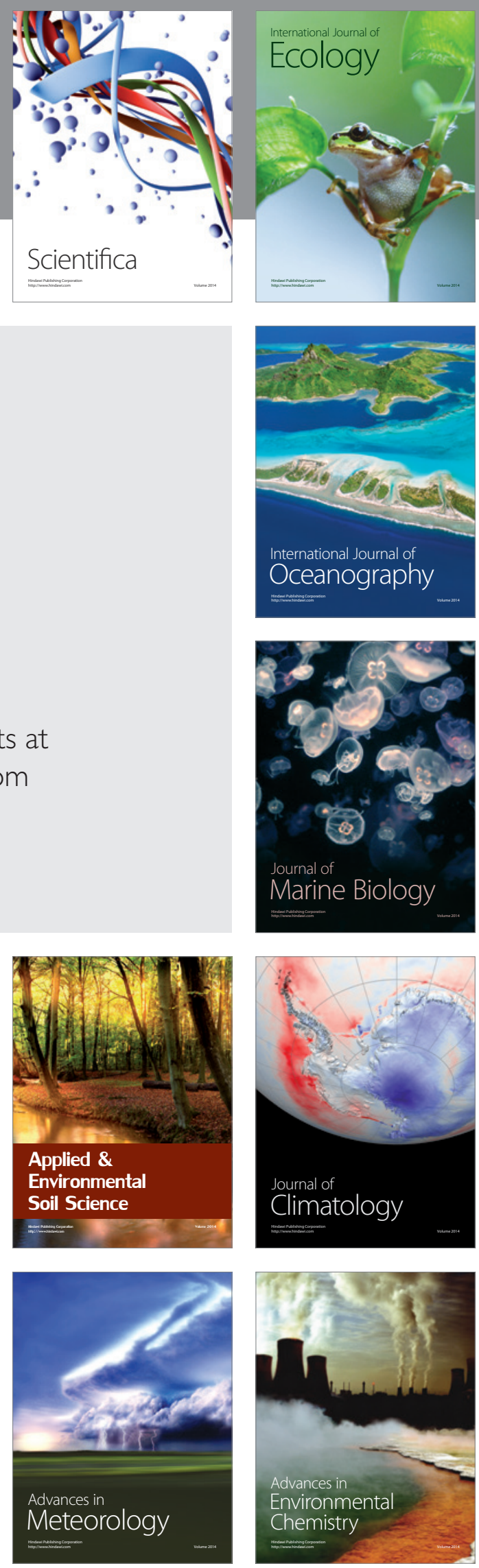